\title{
FREDERIC WILLIAM MAITLAND
}

\section{A Memoir by the late Mrs. Reynell ${ }^{1}$}

IT has been suggested that a notice of Professor Maitland from one who may claim to have known him all his life would be acceptable, and it is especially suitable that an accurate account should be given of one who was so careful in his own statements.

Many years ago a friend was wont to say that much might be expected from one who had two such grandfathers and such a father, so something should be said of each of them; or perhaps one might begin sooner, for this reason-landed property at Brookthorpe and Harescombe came into the possession of Alexander Maitland by his marriage with Caroline Busby in 1785, and the late professor was, up to the time of his death, known in Gloucestershire as 'Squire Maitland'. Their only son was Samuel Roffey Maitland, who was librarian at Lambeth in the days of Archbishop Howley. It has been often mentioned that there was much similarity in the tastes of the grandfather and grandson. A letter from Professor Maitland written in 1891 may show the influences of the one on the other and is sufficiently characteristic to be interesting. His sister had asked him whether their grandfather's books would live. He wrote :-

'I can well imagine that the grandfather does not receive unbounded admiration from you. But judging him merely as I should judge any other literary man, I think him great. It seems to me that he did what was wanted just at the moment when it was wanted, and so has a distinct place in the history of history in England. The Facts and Documents (illustrative of the History, Documents and Rites of the Ancient Albigenses and Waldenses) is the book that I admire most. Of course it is a book for a few, but then those few will be just the next generation of historians. It is a book which " renders impossible" a whole class of existing

\footnotetext{
1 Mrs. Reynell was Maitland's eldest sister. The article on him in the Dictionary of National Biography by B. Fossett Lock refers to an unpublished memoir by her. When I was writing a lecture in commemoration of the centenary of Maitland's birth, I obtained, through the kindness of Miss Maitland, a copy of the memoir, which, I then found, existed only in mimeograph. As it seemed to me that it would be annoying for any future student interested in Maitland to know of the existence of such a document but not to have access to it, I asked Miss Maitland to obtain from Mrs. Reynell's family permission for the memoir to be published in the Cambridge Law Journal. 'This permission, gladly given, is warmly appreciated.-H.A.H.
} 
books. I don't mean physically impossible, men will go on writing books of that class-but henceforth they will not be mistaken for great historians. One has still to do for legall history something like the work that S.R.M. did for Ecclesiastical historyto teach them, e.g., that some statement about the thirteenth century does not become the truer because it has been constantly repeated,-that " a chain of testimony" is never stronger than its first link. It is the "method" that I admire in S.R.M. more even than the style or the matter-the application to remote events of those canons of evidence which we should all use about affairs of the present day-e.g., of the rule which excludes "hearsay". You see how easily I run off into a lecture.

I am just sending off a paper on Becket to the English Historical. It may interest you more than anything else that I have written'.

Of John Gorham Maitland, the present writer would prefer allowing another to speak. He was one 'the extent of whose powers and attainments his great modesty veiled from the world. At Cambridge he seemed never to have any work to do, yet he was third Classic of his year, second Chancellor's Medallist and seventh Wrangler. His mind embraced all subjects and was as fitted for the work of life as for speculation' (Macmillan's Magazine, November, 1864). Like his son, he held high office at the Union while in Cambridge, and not obtaining success at the bar, had to fill up his leisure time until he found another sphere-he became Secretary to the Civil Service Commissioners. He did not turn to the British Museum for occupation-there are political pamphlets which were at the time successful-he wrote for a while for the Morning Chronicle, and there are translations of German poems which at one time he thought of publishing. He married in 1847, Emma, second daughter of John Frederic Daniell, one of the first Professors at King's College, London, the friend and colleague of Wheatstone and Faraday, whose discoveries in Natural Science gained for him the three medals of the Royal Society and various other distinctions.

Frederic William Maitland was born in Guildford Street on May 28, 1850. His parents left the house shortly afterwards, so that the first home he could remember was 39 Woburn Place. His mother died after a very short illness on December 26, 1851. At that time her elder sister, Charlotte Louisa, came to live with her brother-in-law and take care of his three children. It was her death in 1880 that parted her from them. Mr. Maitland's love of German led him to wish that his children should learn it well, and they were early taught to speak it. Professor Maitland owed much, it is said, to German writers, and in a letter written to one 
of his sisters, probably when he was translating Dr. Giercke's work, there was this phrase - 'blessed be all your German governesses'. He dropped his German at school having only a few lessons at Eton, but resumed it at Cambridge, when he was planning a tour in Germany.

Frederic had been to begin with somewhat delicate, but he gradually outgrew this. He was always fond of music, but for many years he was more remarkable for eager interest in everything and for general activity of mind than for any more special gift. Life was uneventful at this time, chiefly varied by visits to grandparents at Gloucester. Frederic's first school was at Brighton, in the house of Mr. Edward Peters, who afterwards took credit for having refrained from 'making a show boy' of him: but he did refrain and contented himself with sending up a pupil who could take an average place at Eton.

His father died on April 27, 1863. He had wished that his son should go to a large public school, having regretted that his own education had been with a private tutor. This wish was carried out, and Frederic went to Eton in the autumn of 1863.

Dr. Maitland was still alive, but his health was already failing, and it therefore fell to the lot of Miss Daniell to take the entire care of her nephew and nieces. Shortly after Frederic's arrival at Eton his tutor the Rev. W. A. Carter accepted an Eton Fellowship, and he therefore migrated to the house of the Rev. E. D. Stone. In this selection and in many other educational matters his aunt acted on the advice of the Rev. J. W. Blakesley (afterwards Dean of Lincoln).

At Eton there was perhaps little to distinguish F. Maitland's life from that of other boys. He played football, was for a while a volunteer, rowed so much that he 'spoilt his style', spent Sunday afternoons in running to St. George's Chapel to hear the anthem, and more than once began the holidays by walking home to Kensington. He worked sufficiently, but he has himself told us that Greek was not a congenial subject, and he gained no special prizes or distinctions until just before leaving, when he was bracketed with two others for the Newcastle-under-Lyme prize and owed his success to a paper on Chaucer. One of the few letters from him that have been kept is amusing :-

' Tomorrow morning I shall arise a reformed Etonian. "My, aint it terrible, what shall we du?" We are going to learn all manner of abominations, have all manner of extra schools, and be turned wholesale into radicals. Today, the 10th of May, 1868, the Fourth Sunday after Easter, the festival of the Blessed Antoninus, Bishop and Confessor, is our last day of unreformed 
bliss. The old Masters are furious (bless their dear old conservative souls!) the young ones jubilant (like a lot of nasty radicals that they are). I have got my choice of five subjects-French, German, Italian, Logic or Political Economy. The choice lies between German and Mr. Wm. Johnson on Political Economy. Bathing is allowed and I got up early this morning and had my first bathe while tutor was in bed : we being allowed to bathe very early on Sundays. I was tried for an oar, in the Dreadnought, but of course, I did not get in, which was no disappointment. I have still just the bare chance of being in the Thetis. Tell Aunt Louisa that I am getting stronger though my voice goes in the evening and has made tutor exclaim several times: it is better though and will, I hope, return very soon. Oh ! tutor's Exam : hangs over me like a great bugbear. By the way why cannot _- be a radical though he wishes to reform us? Give it up? Because he is only a Curly W(h)ig. Eugh! After that I had better go to Chapel, don't you think, so good-bye'.

Maitland left Eton in the summer of 1869 , and after a short tour in Switzerland in the course of which he astonished an elder travelling companion by feats of walking, he entered at Trinity College, Cambridge, on the side of the Rev. Robert Burn. For the first year he read Mathematics, but in other respects carried on much the same life as at Eton, winning a prize in the Freshman's Mile Race, and achieving the honour of being sent as a freshman with Mr. Edward Hawtrey to run the three mile race at the Oxford and Cambridge sports.

It is not ill-natured to tell a story he so often told himself and commended to the consideration of those who had the guidance of young men. His words were-' I should never have succeeded if I had not failed once'. Will anyone ever care to look out his place in the Trinity May Examinations? An invitation to go to Eton with friends was promptly refused with the saying :- ' I could not meet my tutor after that'. New times were coming. He became aware that Mathematics was not his line, also it can scarcely have been at any other time than this that 'the idle whim of an idle undergraduate' took him into Mr. Sidgwick's Lecture Room. $\mathrm{He}$ has himself told us of this, and the speech can be read in $\mathrm{Mr}$. Sidgwick's Life. (May it be noticed that 'idle' is his own word-no one else's-his mind was always at work but he had not yet concentrated it on any particular branch of study-this does not suit Examiners.) Whatever the causes were the facts are evident. F. Maitland changed the subject of his reading from Mathematics to Moral Science, resolutely sent away the piano which he thought had led to 'idleness', and gave up Athletic Sports although 
he kept up some rowing which he thought less likely to prove distracting. His first lodgings were alone in Malcolm Street, afterwards he had rooms in Sidney Street with Mr. Clinton Dent, still later Mr. (now Dr.) Cunningham joined him, and the two, friends rather than rivals, read for a Moral Science Scholarship at Trinity. To the joy of at least one of them the Authorities made room for both, and they both obtained Scholarships. This brought Maitland many new friends, and he often afterwards alluded to the change that joining the more brilliant set of undergraduates at the Scholars' Table in Hall made to him. He became well known at the Union, in course of time president, joined a number of various associations of an intellectual sort, was bracketed with Dr. Cunningham, first in the Moral Science Tripos, and took his Degree on January 25, 1878. During the following Long Vacation he stayed up in Cambridge to read for the Whewell Scholarship which he obtained in the Michaelmas Term.

As an undergraduate he had begun keeping terms at Lincoln's Inn, but about this time the chance of obtaining a Moral Science Fellowship turned his mind in another direction. He wrote of himself as ' too poor and too ambitious' to care to meet a failure at the bar, and added that he knew the 'price of success', the giving up reading and study which had 'become very dear' to him. (Perhaps it should be said that in this case the receiver quotes from memory not from an existing letter.) It is well known that Professor James Ward obtained the Fellowship; also it is, or was, well known in Cambridge that the decision which the Examiners had to make was not an easy one. It only remains to be said that the spare copies of the rejected candidate's essay on Political Philosophy were sent to Mr. Sidgwick for circulation among his pupils, showing appreciation from one of whom near the end of his life Professor Maitland still spoke-as ' his Master'.

From this time until 1885, he lived in London with his family, reading first with $\mathrm{Mr}$. Upton a Conveyancer and afterwards with Mr. B. B. Rogers.

His college friend Dr. Verrall was at this time his fellow pupil and for a while shared Chambers with him. His keen interest in practical law has been commented on by others and shews itself in his literary work. There were many other interests and pursuits : he delighted in the Opera, perhaps chiefly in Wagner's works, in Concerts at the Crystal Palace and St. James' Hall, and whenever he could leave his work in London, in adventurous walking on Dartmoor, in Wales, and Scotland. There were at least two foreign tours in 1873 and 1881. On the first occasion he started with friends and remained alone after their return, joining his family at 
Bonn for the Schumann Commemoration and going with them to Switzerland. He long afterwards said he had gained much from being alone at Munich and entering for a while into German life. The direction of the other tour was through Switzerland over the Simplon to Bavens, but there were many excursions. As to the ever-increasing development of his non-professional work, we have his own words spoken in his Inaugural Lecture. ' $I$ had not the advantage of studying Law at Cambridge otherwise perhaps I should not have been a barrister of seven years' standing before I had any idea of the whereabouts of the first hand evidence for the law of the Middle Ages'. In other words there were at least seven years to be filled up before he found the work that suited him best. (The date of the Pleas of the Crozen for the County of Gloucestershire, his first considerable work on legal history, is 1884.) During this time he lectured on political economy at Rochdale and elsewhere, began but did not at that time publish a translation from Savigny and wrote various magazine articles: among these he devoted much time and thought to a series on Herbert Spencer in Mind, and there is an article in the first number of the English Illustrated Magazine on the old and new Law Courts which has interested general readers; Justice and Police, a small work in the English Citizen series, was written at this time. F. Maitland also took interest in the University Extension Scheme, trying to establish lectures near his home in Kensington and lecturing at another centre on Political Philosophy. Somewhat later he gave fortnightly lectures at Liverpool University. He has recorded his first introduction to Sir Leslie Stephen in 1880 and written of the Sunday Tramps and Scratch Eight : perhaps he does not say enough of his contributions to the Dictionary of National Biography. In 1883 he again went abroad with his sister joining Mr. and Mrs. A. J. Butler in the Tyrol; this journey has lately been described in the Athenæum. In the midst of varied occupation there was however some feeling of disappointment. 'Only a few of the men who choose that profession (the Law) can succeed in it : the qualities which make a man a great lawyer are rare and space on the woolsack is strictly limited. The Cambridge Law Student should be prepared for either fortune. The day may come when in bitterness of his soul he will confess that he is not going to succeed, when he is weary of waiting for that Solicitor who never comes, when the prolonged and costly education seems thrown away.' These are his own wordshe was to succeed in another line. A casual observation can be remembered-' Professor. Sidgwick will not leave him alone till he gets him at Cambridge'. Is it not a proof of the Knightbridge Professor's discernment that he should have seen that he would 
thus be bringing a man into his right place? There had been other suggestions as to Cambridge work; at length the Readership of English Law was established at the end of 1884 and Maitland returned to Cambridge, first to lodgings, afterwards to rooms in Trinity-he had found his vocation in life and he knew that he had done so.

In 1886 he married, at Brockenhurst, Hampshire, Florence Henrietta, daughter of Mr. H. L. Fisher, Vice-Warden of the Stannaries and niece of his friend Mr. Leslie Stephen. For a short time they lived at Brookside, but on the death of Professor Birkbeck in 1888, the Reader succeeded him as Downing Professor of the Laws of England and went to Downing.

In 1887 he had completed a larger work than he had hitherto. published-an edition of Bracton's Note Book. His first work for the Selden Society in which he was so much interested for the remainder of his life appeared in 1888.

This notice may well end here. There are others who can tell more of his strenuous University life, of his rising fame and honours, of his brave struggle against ill health, of his gentle and beautiful life at home; it has rested with one who loved him all along to show how he gradually settled down to work and gradually discovered the work that it was best for him to do. 